\title{
PHILOSOPHY AND POLITICAL AGENCY IN THE WRITINGS OF FREDERICK II OF PRUSSIA*
}

\author{
AVI LIFSCHITZ \\ University of Oxford
}

\begin{abstract}
Frederick II's writings have conventionally been viewed either as political tools or as means of public self-fashioning - part of his campaign to raise the status of Prussia from middling principality to great power. This article, by contrast, argues that Frederick's works must also be taken seriously on their own terms, and interpreted against the background of Enlightenment philosophy. Frederick's notions of kingship and state service were not governed mostly by a principle of pure morality or 'humanitarianism', as argued influentially by Friedrich Meinecke. On the contrary, the king's views were part and parcel of an eighteenth-century vision of modern kingship in commercial society, based on the benign pursuit of self-love and luxury. A close analysis of Frederick's writings demonstrates that authorial labour was integral to his political agency, publicly placing constraints on what could be perceived as legitimate conduct, rather than mere intellectual window-dressing or an Enlightened pastime in irresolvable tension with his politics.
\end{abstract}

It is often forgotten that the first monarch discussed at the outset of Alexis de Tocqueville's classic, The ancien régime and the French Revolution (1856), is neither Louis XVI nor his predecessors, but rather Frederick II of Brandenburg-Prussia (1712-86), widely known as Frederick the Great. Having died three years before the Estates General convened at Versailles, the Prussian monarch is not the first person who comes to mind when the French Revolution is at stake. Yet when Tocqueville considered the surprising shockwaves the Revolution sent through Europe, he had no better reference than Frederick. Other heads of state could be expected to miss forewarnings and early symptoms of the revolutionary outbreak - but Frederick should have known better, according to Tocqueville in Book I, Chapter I of The ancien régime.

<extract>

Not even Frederick the Great, for all his genius, sensed what was coming. He was in contact with it yet failed to see it. Indeed, his actions were in accord with the spirit of the Revolution before the fact.

Magdalen College, Oxford, ox14AU avi.lifschitz@history.ox.ac.uk

* The article is based on the annual Quentin Skinner Lecture in Modern Intellectual History at the University of Cambridge, April 2018. I am grateful to the electors to the Quentin Skinner Fellowship for the invitation to deliver the Lecture, and to the discussants and audience at Cambridge for helpful suggestions and comments. The main arguments and examples also appear in the introduction to Frederick the Great's philosophical writings, ed. Avi Lifschitz, trans. Angela Scholar (Princeton, NJ, 2021). 
He was its precursor and, in a manner of speaking, its agent. Yet he did not see it looming on the horizon. ${ }^{1}$

What did it mean to see Frederick the Great in 1856 as a precursor and even an agent of the French Revolution? How was Frederick 'in contact' or 'in accord' with the Revolution or its spirit? And why was this specific monarch singled out by Tocqueville as a so-called revolutionary ruler, when in fact - as Tocqueville knew only too well - he headed one of the most absolutist regimes in eighteenth-century Europe?

These questions should not necessarily be answered by reference to the monarch's military and political feats. It was mostly his authorship and profuse writings that left such a profound impact on contemporary and subsequent political thinkers. Particularly in the decades immediately preceding and following his death in 1786, Frederick's oeuvre formed part of a significant debate over the limits of state power and the proper extension of the freedom of thought and expression. Only in the late nineteenth century, and throughout the twentieth, Frederick's image became almost exclusively focused on his military exploits, while relatively little attention was paid to his writings. This article constitutes an attempt to shift the balance between philosophy and political action in the monarch's historical image. Its main argument is that the act of writing and publishing was not only window-dressing, a mere instrument allowing the king to present himself as an eighteenth-century incarnation of a Platonic philosopher-king or a Marcus Aurelius.

The spectacle of an absolutist ruler who wrote and published prolifically was rare and extraordinary indeed: writing for the public at large was an occupation beneath the dignity of hereditary monarchs. The crowned heads of Europe could easily commission advisers, ministers, and men of letters to convey specific messages in case of need, while writing directly to individuals or circumspect groups of addressees. In the eighteenth century, several monarchs, such as Catherine II of Russia or Stanisław August Poniatowski of Poland-Lithuania, were engaged in extensive correspondence with renowned authors, the equivalents of modern public intellectuals. But most monarchs who were writers signalled their amateur status in the field of philosophy.

Frederick, however, identified himself as an intellectual from the age of sixteen, when he signed a letter as Fédéric [sic] le philosophe: ${ }^{2}$ throughout his career he never shied away from situating himself in the intellectuals' own arena. For him, stooping to publish in the eighteenth-century print market was not only a magnanimous act of patronizing the arts or demonstrating one's sharp wit. It involved exposing oneself inescapably to all aspects of contemporary publishing, including its disagreeable elements: unflattering reviews, refutations, ad hominem attacks, pirated and mutilated editions, and witnessing one's arguments taken out of context. Another highly unusual feature of Frederick's authorship is the reputation his works enjoyed (or suffered) and their subsequent use in debates on political reform, Enlightenment, censorship, freedom of conscience, and the remit of governmental power. Radicals and conservatives alike have referred to telling aspects of the king's writings.

\footnotetext{
${ }^{1}$ Alexis de Tocqueville, The ancien régime and the French Revolution, ed. Jon Elster, trans. Arthur Goldhammer (Cambridge, 2011), p. 11; Alexis de Tocqueville, L'ancien régime et la Révolution, ed. J.-P. Mayer (Paris, 1967), p. 57.

${ }^{2}$ Reinhold Koser, Friedrich der Große als Kronprinz (Stuttgart, 1886), 135.
} 
Frederick's conquest of Silesia (1740-2), its successful defence in the Second Silesian War (1744-5) and in the Seven Years War (1756-63, fought against a coalition of the mightiest land-based powers in Europe), as well as the first partition of Poland (1772), may all account for his status as a 'great' king of Prussia, a designation he endorsed and amplified through a variety of means. ${ }^{3}$ From this perspective, his writings may indeed seem an instrument of shrewd self-promotion. The question of their significance has been frequently raised due to the perceived contradiction between Frederick's political agency and his philosophical writings. Historians have tried to plumb the depths of what they saw as an abyss separating Frederick the Enlightenment author, ally of the French Encyclopédistes, and the absolutist king of Prussia who had no compunction about launching first a war of conquest in Silesia and then a partition of Poland-Lithuania, maintaining the nobility's traditional privileges, and tightening the already firm link between military and society.

The view of Frederick's writings as cynical ploys in the political and cultural spheres is not new. Shortly after the Napoleonic Wars, the reactionary author Karl Ludwig von Haller argued that Frederick II, in a manner characteristic of other reforming monarchs, deviously used whatever he had learned from natural law theorists to empower himself and extend the reach of his supposedly modernized state. For Haller, this amounted to painting a false philosophical veneer over the most egotistic and despotic regime of the time. But it was also a perilous game, in Haller's eyes, for some of the ideas Frederick advocated in public could also be appropriated by radicals and revolutionaries. ${ }^{4}$ While more recent accounts have been less ideological, the chasm between the ruler's conduct and the author's writings has remained ominously deep. In his renowned work of 1924 on reason of state, Friedrich Meinecke saw Frederick's reign as a protracted struggle between humanitarian philosophical drives (ethos) and pragmatic, at times crude power politics (kratos), even if the king's function as ruler always preceded his philosophical persona. ${ }^{5}$ Some sixty years later, this Janus-faced interpretation dominated Theodor Schieder's biography of Frederick, subtitled 'a kingship of contradictions' ${ }^{6}$ The frequent resort

${ }^{3}$ On Frederick's orchestration of his own 'greatness', see Jürgen Luh, Der Große. Friedrich II. von Preußen (Munich, 2011); Thomas Biskup, Friedrichs Größe. Inszenierungen des Preußenkönigs in Fest und Zeremoniell, 1740-1815 (Frankfurt am Main, 2012); Katrin Kohl, 'Publizistische Inszenierung von Größe. Friedrichs Schriften als Medium des Ruhms', in Stiftung Preußische Schlösser und Gärten, Friederisiko: Friedrich der Große. Die Essays (Munich, 2012), pp. 26-35.

${ }^{4}$ Karl Ludwig von Haller, Restauration der Staats-Wissenschaft, oder Theorie des natürlich-geselligen Zustands, der Chimäre des künstlich-bürgerlichen entgegengesetzt (2nd edn, 6 vols., Winterthur, 1820), II, pp. 188-92. See also Béla Kapossy, 'Karl Ludwig Haller's critique of liberal peace', in Béla Kapossy, Isaac Nakhimovsky, and Richard Whatmore, eds., Commerce and peace in the Enlightenment (Cambridge, 2017), pp. 244-71.

${ }^{5}$ Friedrich Meinecke, Die Idee der Staatsräson in der neueren Geschichte (Munich, 1924), 1-20, 350-73.

${ }^{6}$ Theodor Schieder, Friedrich der Große. Ein Königtum der Widersprüche (Frankfurt am Main, 1983), abridged as Frederick the Great, trans. Sabina Berkeley and H. M. Scott (London, 2000). 
to such terms as antinomy, irreconcilability, or contradiction where Frederick and his writings are concerned betrays a basic assumption about the link between the written word and political action: if it cannot be demonstrated that Frederick pursued in practice the principles apparently avowed in his writings, the philosophical works must have been duplicitous masks in a ball of Realpolitik. ${ }^{7}$

Several points should be borne in mind in response to this line of argumentation. The first is that the king's writings deserve to be analysed and studied on their own terms, whether they were compatible with his political conduct or not. When approaching Frederick's works, we would do well to ask why they were considered so surprising at the time as to attract such a broad range of responses. What were the intellectual strands that moulded the king's works? Who (and what) did Frederick engage with and reply to? An analysis of the substance of the king's writings does matter for the intellectual history of the eighteenth century (and beyond), irrespective of the function of such works within their most immediate political contexts. It highlights the legitimate ways of presenting oneself as pursuing specific lines of action, while enabling us to understand how contemporaries perceived Frederick's philosophical writings and used them for various purposes.

The king's analytic acumen may not have equalled Immanuel Kant's, but philosophical originality of the first order was never his purpose. A philosopher-king was a creature very different from an academic philosopher. Yet while the king argued that he never wished to construct philosophical systems, and did not lay claim to unparalleled originality, he did concoct a unique synthesis out of modern and ancient ingredients through constant dialogue with some of the best minds of the French Enlightenment. It is his personality and status that made his writings startling, at times shocking, as well as the sheer quantity and diversity of his works (collected in thirty substantial volumes of the Preuß edition, accessible online). ${ }^{8}$ Over more than half a century, Frederick composed discourses, reviews, histories, theatre plays, dialogues of the dead, satirical pamphlets, and - importantly - philosophical poems and epics (his preferred genre of writing) on top of a sprawling correspondence with poets, philosophers, mathematicians, and other men of letters. The variety, volume, and thematic range of Frederick's philosophical authorship attests in itself to its significance in the king's life; he frequently complained about his uncurable addiction to philosophizing and versifying. ${ }^{9}$ If he had merely wished to boast of his superior intellectual ability and advertise himself as a roi-philosophe, much less would have been required to make the point.

Furthermore, Frederick's works merit serious attention regardless of his sincerity or disingenuousness at the time of writing, psychological notions better left outside the historian's remit. ${ }^{10}$ Once again, we could do worse than listen to the king's

\footnotetext{
${ }^{7}$ See, most recently, Andreas Pečar, Die Masken des Königs. Friedrich II. von Preußen als Schriftsteller (Frankfurt am Main, 2016).

${ }^{8}$ Euvres de Frédéric le Grand, ed. Johann David Erdmann Preuß (30 vols., Berlin, 1846-56) (henceforth $O F G$ ). This edition is freely accessible online at http://friedrich.uni-trier.de/.

${ }^{9}$ An early example can be found in Frederick's letter to Voltaire, 12 June 1740 (D2233), in Euvres complètes de Voltaire, ed. Theodore Besterman et al. (Geneva and Oxford, 1968-2021) (henceforth $O C V$ ), XCI, p. 205.

${ }^{10}$ See Quentin Skinner's distinction between recoverable discursive intentions and irretrievable psychological motives in 'Motives, intentions and interpretation', in
} 
contemporaries in this respect. Upon the appearance of Frederick's first published work, Anti-Machiavel, it was not only the incongruity between its apparent endorsement of international morality and the invasion of Silesia that puzzled readers. They were primarily perplexed by the curious phenomenon of a publishing monarch. As the duc de Luynes observed at the French court, 'a Prince who establishes publicly and almost under his own name such wise principles of government, which are nevertheless so rarely practiced in a precise manner, contracts in a way an engagement with the public that is very difficult to realise to its fullest extent'. ${ }^{11}$ The duc de Luynes's puzzle did not concern a tension between the content of Frederick's work and his political conduct, but rather the young king's willingness to impose severe constraints on the scope of his publicly legitimate action. Genuine or dissimulating as Frederick may have been at the time of writing, his works acquired an independent lease on life in the public sphere. ${ }^{12}$

\section{II}

Another key to exorcising the ghost of the supposedly irresolvable contradiction between the king's printed ideas and his political agency is the recognition that the contrast is not as sharp as it has usually been portrayed. Frederick would have been the first to confirm that the notion of kingship portrayed in his writings was a regulative ideal rather than a realistic account of eighteenth-century politics. Moreover, it was far from a self-denying, idealistic conception of government.

As early as the first chapter of the Anti-Machiavel (1740), Frederick introduced the ideas with which he has become identified ever since: the king was the first servant of the state, and royal authority originated in a social contract. ${ }^{13}$ While the first references to a social contract were made early on, as late as 1777 the term pacte sociale appeared seven times in Frederick's Essay on the forms of government. If these major aspects of Frederick's political theory, the ruler's servitude to the state and the appeal to a social contract, have usually been seen as discrete elements, they essentially stem from the same seventeenth-century model developed by natural law theorists such as Thomas Hobbes and Samuel Pufendorf. (The latter served Frederick's grandfather, Frederick I, as royal historiographer and privy councillor.) ${ }^{14}$

Visions of politics (3 vols., Cambridge, 2002), I, pp. 90-102. On self-imposed constraints and the question of sincerity, see Skinner's 'Augustan party politics and Renaissance constitutional thought', in Visions of politics, II, pp. 344-67.

${ }^{11}$ Charles-Philippe d'Albert, duc de Luynes, Mémoires du duc de Luynes sur la cour de Louis XV, 1735-1758, III, ed. Louis Dussieux and Eudore Soulié (Paris, 1860), p. 267.

${ }^{12}$ See section IV below.

13 'The sovereign, far from being the absolute master of the people who are under his domination, is himself only their first servant.' ('Anti-Machiavel', in Frederick the Great's philosophical writings, ed. Avi Lifschitz, trans. Angela Scholar (Princeton, NJ, 2020), p. 15). (henceforth $F G P W$ )

${ }^{14}$ On the differences between Pufendorf's historical works and Frederick's own accounts of his dynasty, see Christopher Clark, Time and power: visions of history in German politics from the Thirty Years' War to the Third Reich (Princeton, NJ, 2019), pp. 72-117; Pečar, Masken des Königs, pp. 33-81. 
In their major works, Leviathan (1651) and De jure naturae et gentium (1672), Hobbes and Pufendorf respectively wished to counter republican arguments about the advantages of self-governing communities. Another prominent target of these contractarian theorists was the monarchomach literature of the sixteenth and seventeenth centuries, which grounded political authority in an original contract as a way of justifying rebellion or dethronement if the monarch had neglected his duties (originally enshrined in the foundational pact). ${ }^{15}$ Despite some theoretical differences, both Hobbes and Pufendorf separated the state from its ruler and the citizens alike; their version of the social contract was more authoritarian than contemporary or subsequent constructs. They rejected the idea that the people, as if they had originally formed a single person, could negotiate the terms of the initial contract. Indeed, one of Hobbes's theoretical innovations was to argue that a 'multitude' of individuals constituted itself as a single body only through their joint submission to a government. ${ }^{16}$ The foundations of the modern concept of an impersonal state are thus to be found, according to Quentin Skinner, in a seventeenth-century theory that was absolutist and secular in its implications due to its elevation of the state above all traditional powers demanding spiritual or civic allegiance. ${ }^{17}$

Frederick usually presented his political ideas in lapidary form, frustratingly sparing where sources are concerned. ${ }^{18}$ Yet the main elements of HobbesianPufendorfian contract theory are clearly present in his works: in particular, it is difficult to ignore their pronounced secular and absolutist overtones. Such similarities should not, however, diminish the shockwaves that Frederick's own writings sent through eighteenth-century Europe. Not only was it the first time that a hereditary king took pen to paper to announce such principles in his own voice: Frederick also added to his contract theory a distinctly modern flavour concerning the pursuit of selflove (to be discussed in the next section).

Royal authority, the king argued, originated in the people's decision to renounce their natural liberties in exchange for security of life and possessions, safeguarded by a ruler they appointed. Frederick did not allow, of course, any opt-out mechanisms justifying rebellion under special circumstances or subjecting the ruler's executive decisions to institutional supervision by representatives of the people. The king alone represented the state, Frederick insisted, by uniting in his person the will of the people. ${ }^{19}$ Nevertheless, he carefully demarcated the political sphere in his writings. While pointing to the well-being of the people as the ruler's main duty,

${ }^{15}$ Quentin Skinner, 'The state', in Terence Ball, James Farr, and Russell L. Hanson, eds., Political Innovation and Conceptual Change (Cambridge, 1989), pp. 90-131; idem, 'From the state of princes to the person of the state', in Visions of politics, II, pp. $368-413$.

${ }^{16}$ Ch. 17 in Thomas Hobbes, Leviathan, ed. Noel Malcolm (Oxford, 2012), II.i, pp. 254-7. For Pufendorf's version: Of the law of nature and nations, trans. Basil Kennet (London, 1717), book VII, ch. 2, p. 476.

${ }^{17}$ Skinner, 'From the state of princes', p. 405.

${ }^{18}$ As Frederick usually read classical and modern philosophy in French, the most probable conduit was Jean Barbeyrac's French translation of Pufendorf's De iure naturae et gentium under the title Le droit de la nature et des gens (Amsterdam, 1706). On Barbeyrac's background in the Huguenot community in Berlin, see Sieglinde Othmer, Berlin und die Verbreitung des Naturrechts in Europa (Berlin, 1970), 60-90.

19 'Essay on the Forms of Government and the Duties of Sovereigns', FGPW, p. 199. 
Frederick interpreted such welfare in a flexible manner, especially concerning the citizens' opinions and beliefs: he repeatedly exhorted his subjects to seek their salvation and happiness in any way they saw fit. This encouragement was paralleled by the king's account of the areas left outside the original contract. As the subjects' opinions and beliefs could have never formed part of the pact, they should be of no concern to modern governments as well.

One would have to be insane to imagine that men have ever said to a fellow man, 'We are raising you above ourselves, because we like to be slaves, and we are giving you the power to direct, as you will, our thoughts.' On the contrary, they said, 'We need you to uphold the laws we wish to obey, to govern us wisely, and to defend us; we demand of you, moreover, that you respect our freedom.' The verdict [on freedom of thought and belief], here, is clear, and cannot be appealed; and this tolerance, moreover, is so favourable to the society in which it is established that it ensures the good fortune of the state. ('Essay on the forms of government and the duties of sovereigns', $F G P W$, p. 205)

This explicit endorsement of contract theory by a ruling monarch was unique at a time of kingship by God's grace. Although fellow monarchs shared some of Frederick's convictions and enacted similar reforms, none went so far as to reject publicly the religious aspects of kingship. And if Frederick appropriated major elements of Hobbes's and Pufendorf's contract theory, his writings clearly constituted a break with a different line of argumentation for absolute monarchy.

Apologists for this form of government used to argue that while tyrants ruled arbitrarily, legitimate kings were restrained by their allegiance to the law of God, natural law, and the fundamental laws of their kingdom. Royal power was, however, as absolute as a father's right over his offspring or God's control of his creation. James VI and I of Scotland and England, the last European monarch before Frederick who wrote extensively on political theory, declared in a speech to the English parliament in 1610 that 'Kings are not only God's Lieutenants upon earth, and sit upon God's throne, but even by God himself they are called Gods. ${ }^{20}$ Relying on the Bible and referring to recent religious wars in which monarchs had been declared heretics, James argued that even if the king failed to rule according to divine laws and those of the realm, only God could hold him to account. ${ }^{21}$ James's library contained a copy of Jean Bodin's Six livres de la république (1576), where he may have encountered some aspects of his own notion of absolute sovereignty. While Bodin did not exclusively discuss monarchies, he insisted that sovereignty 'is not limited in power, or in function, or in length of time'. ${ }^{22}$ Elective monarchs or kings who ruled on behalf of the estates did not enjoy absolute sovereignty, for 'the main point of

\footnotetext{
20 'Speech to parliament of 21 March 1610', in King James VI and I, Political Writings, ed. Johann P. Sommerville (Cambridge, 1995), p. 181 (modernized orthography).

${ }^{21}$ See also 'The Trew Law of Free Monarchies', ibid., 62-84.

${ }^{22}$ Bodin, On Sovereignty, ed. Julian H. Franklin (Cambridge, 1992), Book I.8.3
} (Bodin, Les Six Livres de la République/De Republica libri sex, Book I, eds. Mario Turchetti and Nicolas de Araujo, preface by Quentin Skinner (Paris, 2013), pp. 448449.) Unlike James VI and I or, subsequently, Bossuet, biblical precedent did not play a central role in Bodin's theory. 
sovereign majesty and absolute power consists of giving the law to subjects in general without their consent'. ${ }^{23}$ A century later, Jacques-Bénigne Bossuet, the renowned propagandist for Louis XIV's absolutist regime, made a similar point by grounding the practical unaccountability of the monarch in biblical examples and a "particular providence' directly intervening in human affairs (in Politique tirée des propres paroles de l'Écriture sainte, posthumously published in 1709). ${ }^{24}$

Frederick, on the other hand, had no time for biblically grounded, divinely warranted justifications of absolute monarchy. Time and again, he employed the social contract as a secular source of royal authority which could nevertheless be reconciled with religious belief. In 1770, replying to an attack on contemporary monarchs, Frederick insisted that he was not writing in defence of God-given royal authority.

We would, moreover, surrender to him [the reviewed author] such titles as 'images of the Divinity' or 'God's representatives', which one attributes to kings so improperly. Kings, like the rest of us, are men; they do not enjoy the exclusive privilege of being perfect in a world where nothing is so. They bring to the throne, upon which an accident of birth has placed them, their timidity or their resolution, their energy or their idleness, their vices or their virtues; and in a hereditary monarchy it must of necessity be the case that princes with very differing characters succeed one another. ('Examination of the Essay on prejudice, , FGPW, p. 177)

Unsurprisingly, this critique of kingship by divine grace and the resort to contract theory were not meant to resuscitate republican notions of self-governance. Frederick disdained the republican stress on formal procedures for the maintenance of self-rule. His Essay on the forms of government (1777) is, if anything, an essay against the theoretical fixation with forms of government from antiquity to the eighteenth century. In this treatise, he made an argument similar to Hobbes's point in Chapter 21 of Leviathan about the citizens of the Republic of Lucca. According to Hobbes, while these ardent republicans might emblaze the word Libertas in great characters on the turrets of their town, a private citizen there did not enjoy greater liberty or 'Immunitie from the service of the Commonwealth' than in Constantinople, under the sultan. ${ }^{25}$ Frederick claimed that forms and institutions of government especially the free state espoused by republicans - were of no great consequence. Monarchy could be the best form of government or the worst, he argued, depending on the way it was administered and whether it promoted the well-being of its subjects.

\section{III}

Despite the unusual spectacle of a hereditary monarch who explicitly expounded such ideas while corresponding with the most renowned French philosophes, Frederick did not espouse Jean-Jacques Rousseau's more radical contract theory, which placed a

\footnotetext{
${ }^{23}$ Ibid., p. 23.

${ }^{24}$ Bossuet, Politics Drawn from the Very Words of Holy Scripture, ed. Patrick Riley (Cambridge, 1990), 245; Politique tirée des propres paroles des l'Ecriture sainte, ed. Jacques Le Brun (Geneva, 1967), p. 272.

${ }^{25}$ Ch. 21 in Hobbes, Leviathan, ed. Malcolm, II.i, p. 332.
} 
premium on popular sovereignty. Nor did he take up, unlike Rousseau and other contemporary authors, the vision of a self-denying and frugal kingship elaborated by François de Salignac de la Mothe-Fénelon in Télémaque (1699), one of the bestselling and most influential books in eighteenth-century Europe.

Fénelon wrote this didactic account of the adventures of Ulysses's son, Telemachus, as tutor to the duke of Burgundy, second in line and later heir-apparent to Louis XIV's throne (before his untimely death in 1712). Télémaque contrasted glory-driven, bellicose rulers of an ancient Roman mould with those committed to promoting the common good of a largely agricultural polity, free of luxury, modern commerce, urban corruption, and expensive wars: this was a de-militarized image of Spartan austerity. Widely interpreted as a vehement critique of Louis XIV's wars and his ostentatious culture of representation, Télémaque prompted its author's fall from royal grace and exile to his northern diocese. Fénelon also managed to attract Bossuet's ire (and the Vatican's censure) for his endorsement of a disinterested love of God beyond any hope for personal salvation or happiness, requiring the total elimination of self-love. In Fénelon's work, the ancient republican critique of selfinterest in the name of the patria was the political incarnation of a pure, wholly disinterested love of God. ${ }^{27}$

It is indeed easy to mistake Frederick's emphasis on the ruler's duties to his subjects and an impersonalized state for a Fénelonian-republican critique of modern politics and commercial society. Perhaps because we know that Frederick's mother admired Télémaque and discussed the book with her son, literature on the king has tended to over-emphasize the subsequent impact of Fénelon's notions of frugality and the absolute prioritization of the public over the self. ${ }^{28}$ In his seminal biography of Frederick, Theodor Schieder argued that Fénelon provided the model for benevolent kingship in the Anti-Machiavel. ${ }^{29}$ Meinecke has suggested that Frederick's ideal of service to the state was inspired by either Fénelon, Pierre Bayle, or a form of Calvinist self-denial that Frederick could never completely shake off, hard as he may have tried. $^{30}$

The king's ideas were, however, altogether more realistic: they were well adjusted to modern reason of state and commercial politics. Frederick argued that a healthy dose of luxury oiled the springs of commerce, manufacture, and (indirectly) even agriculture. More generally, he was well aware of the substantial distance separating his own age from Machiavelli's: he did not condemn the latter's Prince only to endorse central tenets of Renaissance (or ancient) republicanism. Referring to

${ }^{27}$ See the introduction to François de Salignac de la Mothe-Fénelon, Telemachus, ed. Patrick Riley (Cambridge, 1994), pp. xiv-xv.

${ }^{28}$ Ernst Bratuscheck, Die Erziehung Friedrichs des Großen (Berlin, 1885), pp. 27-8; Eduard Zeller, Friedrich der Große als Philosoph (Berlin, 1886), pp. 237-8.

${ }^{29}$ Schieder, Friedrich der Große, p. 105; Schieder, Frederick the Great, p. 77. Schieder notes that Frederick contrasted at the outset of chapter VII of Anti-Machiavel an angelic Fénelon to a demonic Machiavelli ( $F G P W$, p. 27). The purpose of this juxtaposition was, however, surely to dismiss both views of morality as exaggerated and non-practical.

${ }^{30}$ Meinecke, Idee der Staatsräson, pp. 350-1. An exception, emphasizing the modern elements in Anti-Machiavel (from a political perspective) is Isaac Nakhimovsky, 'The enlightened prince and the future of Europe: Voltaire and Frederick the Great's AntiMachiavel of 1740', in Kapossy, Nakhimovsky, and Whatmore, eds., Commerce and Peace, pp. 44-77. 
the qualitative difference between modern standing armies and the mercenaries employed by the miniature rulers of Italian city-states (principini), Frederick argued that the enormous costs of modern warfare provided a powerful incentive for the maintenance of peace. Furthermore, a modern economy founded on the division of labour allowed eighteenth-century states to operate much more efficiently than selfgoverning republics, where each citizen was also potentially a soldier.

The unique advantage of this [earlier] arrangement was that the military cost nothing in times of peace, but that, when the call to arms sounded, every citizen became a soldier, whereas, at present, these roles are separate: the farmer and the manufacturer each continues his own work, without interruption, while that section of the citizens destined to defend the others performs its duty...It thus follows from our modern practice that our wars are shorter than those of our forebears, less ruinous to the lands that provide the theatre of war, and that we owe to the great expense that wars involve those brief moments of peace that we enjoy, and which, moreover, the exhaustion of the great powers will probably lengthen. ('Examination of the Essay on prejudice', FGPW, p. 176)

These views originated in Frederick's (as yet understudied) engagement with the European luxury debate, where he positioned himself at the ideological pole opposite to Fénelon's. The eighteenth-century luxury debate was not only, or even mainly, confined to political economy: it was a controversy over the values of a modern, commercial, and globalized society, as well as a discussion of human nature and its basic instincts. The debate gave rise to the first enthusiastic apologies for an economy based on the division of labour, relentless growth, and inequality - as well as to blistering critiques of modern civilization such as Jean-Jacques Rousseau's Discourse on inequality (1755). ${ }^{31}$ Initially linked to the Quarrel of the Ancients and the Moderns around the turn of the century over the comparable merits of classical and modern literature, the luxury debate gradually diverged from the early Quarrel on account of its more explicit emphasis on political economy and ethics. Moralists of either Christian or republican leanings (or both, in Fénelon's case) criticized luxury as the untrammelled pursuit of self-interest and its prioritization over the common good. They usually recommended overcoming self-regarding instincts by focusing on human reason, God's grace, or future salvation. Their opponents recognized, however, that the passions held sway over fragile human reason, and professed agnosticism concerning future rewards and punishments. Damned or saved in another life, human beings had to pursue their self-love in this world since they could not do otherwise - and because the satisfaction of such passions gave rise to unprecedented

\footnotetext{
${ }^{31}$ The literature on the luxury debate is vast. A partial list would include Albert Hirschman, The passions and the interests: political arguments for capitalism before its triumph (Princeton, NJ, 1977); István Hont and Michael Ignatieff, eds., Wealth and virtue: the shaping of political economy in the Scottish Enlightenment (Cambridge, 1983); Christopher Berry, The Idea of luxury: a conceptual and historical investigation (Cambridge, 1994); István Hont, Jealousy of trade: international competition and the nation-state in historical perspective (Cambridge, MA, 2005); idem., 'The early Enlightenment debate on commerce and luxury', in Mark Goldie and Robert Wokler, eds., The Cambridge history of eighteenth-century political thought (Cambridge, 2006), pp. 379-418.
} 
economic and cultural prosperity. For its advocates in different forms, such as Bernard Mandeville, Voltaire, Montesquieu, David Hume, and Adam Smith, luxury became a proxy for modern culture tout court: Hume, for example, renamed his essay 'Of luxury' (1752) as 'Of refinement in the arts' (1760).

Connotations and overtones were significant in this context, following centuries of denunciations of luxury as sinful voluptuousness. The prerequisite for this condemnation was a sharp distinction between the necessary and the superfluous. For the critics, almost anything beyond basic and peaceful subsistence, preferably in a rural setting, was yet another sprig in the tangled thicket of luxury - from commercial commodities to technological advances to intellectual endeavours. The adherents of modern luxury attempted to undermine such notions by redefining luxury as the simple pursuit of human happiness and improvement in this world (rather than the next) - or 'the use of riches and industry to acquire a more comfortable existence', as luxury was defined in 1765 in the Encyclopédie. ${ }^{32}$ Within the pro-luxury camp, this moderate pursuit of comfort and self-love was seen as an agent of civilization and peace, as suggested in Montesquieu's vision of 'sweet commerce' (doux commerce) in De l'esprit des lois (1748). ${ }^{33}$ Early societies, biblical or classical, may have been virtuous but also uncouth and poor in comparison to eighteenth-century Europe.

While Voltaire joined the fray in the early 1730s, his involvement in the luxury debate intensified in 1736 - precisely when his correspondence with Frederick was launched. Commerce, toleration, and the flourishing arts - all seen as effects of the benign pursuit of luxury - had already stood at the centre of Voltaire's Lettres philosophiques (1734), presenting an idealized image of England following the author's sojourn in London from 1726 to 1728 . The Lettres were concluded by an attack on Pascal, who - together with other austere Jansenists - was condemned for his Augustinian view of a fallen human nature. The 25th Letter, on Pascal, was an affirmation of the human condition in the here and now: for Voltaire, God must have created human beings with all their current instincts in place, including their basic penchant for self-love. ${ }^{34}$ The contrast with Pascal's or Fénelon's search for a purer, disinterested human condition was clear.

In the mid-1730s, Voltaire and his lover, Émilie Du Châtelet, studied Alexander Pope's defence of fallen human nature in his Essay on man (1733-4). Voltaire also appreciated the pro-luxury points in Jean-François Melon's Essai politique sur le commerce (1734), yet another endorsement of modern commerce against calls for austere virtue. In 1735-6, Du Châtelet was working on a translation of Bernard Mandeville's Fable of the bees (1714), subtitled 'Private vices, public benefits', a major apology for the pursuit of luxury and self-love. Du Châtelet, in collaboration with Voltaire, attempted to remove Mandeville's more radical views

\footnotetext{
32 Jean-François de Saint-Lambert, 'Luxe', in Denis Diderot and Jean-Baptiste le Rond d'Alembert, eds., Encyclopédie, ou Dictionnaire raisonné des sciences, des arts et des métiers, IX (Neuchâtel, 1765), pp. 763-71 (at p. 763).

33 'Commerce cures destructive prejudices, and it is an almost general rule that everywhere there are gentle mores, there is commerce and that everywhere there is commerce, there are gentle mores' (Book XX, ch. 1, in Montesquieu, The spirit of the laws, trans. A. M. Cohler, B. C. Miller, and H. S. Stone (Cambridge), p. 338; 'De l'esprit des lois', in Euvres complètes, ed. Roger Caillois (2 vols., Paris, 1949-51), II, p. 585).

${ }^{34}$ Letter 25 in Voltaire, Philosophical letters; or, letters concerning the English nation, ed. John Leigh, trans. Prudence Steiner (Indianapolis, IN, 2007), p. 103.
} 
from his endorsement of modern culture. In Du Châtelet's version, natural virtue was tightly linked both to the common good and to a healthy pursuit of self-love: the latter was no longer a 'private vice'. ${ }^{35}$ This also became the theme of the final chapters of Voltaire's posthumously published Traité de métaphysique (completed in 1736): some of its draft chapters were sent to Frederick in $1737 .^{36}$

In summer 1736, when Frederick first contacted Voltaire, the latter was writing Le Mondain - his most renowned intervention in the luxury debate. The uproar caused by its pirated publication prompted Voltaire to issue a Défense $d u$ Mondain in 1737. In biting rhymed verse, Voltaire ridiculed anyone advocating a return to a biblical, classical, or any other bygone golden age of noble austerity. Le Mondain was a hymn to the present 'iron age' of global commerce and modern living standards, from basic comforts to painting, music, and the popping corks of Champagne bottles (a recently developed product). ${ }^{37}$ While Le Mondain immediately became scandalous for its portrayal of Adam and Eve as a boorish couple with long dirty nails and frazzled hair, living indigently in Eden, the poem's clear target was Fénelon's Télémaque (explicitly discussed towards its end). Voltaire consistently revaluated and lavished praise on the terms most intensely condemned by Fénelon: abundance, luxury, superfluity, and softness (mollesse). These were, for Voltaire, the surest guarantors of industry and prosperity in modern Europe. The poem's most famous line, 'Le superflu, chose très nécessaire' ('the superfluous, such a necessary thing') was not just a succinct, memorable slogan. ${ }^{38}$ The equivalence Voltaire drew between the necessary and the superfluous undermined the entire differentiation between nature and artifice, or between basic subsistence and luxury - a distinction underpinning all contemporary critiques of modernity.

These insights, at both the psychological and political levels, appear in the very first letters and poems Voltaire sent Frederick in late 1736. Encouraging the young Hohenzollern to cultivate his passion for philosophy and poetry - and to philosophize in verse - Voltaire also emphasized that learning should not come at the expense of a worldly, engaged lifestyle that involved the pursuit of self-love: Frederick should not become a pedantic scholar or sacrifice his political calling on the altar of philosophy. ${ }^{39}$ In a rhyming poem for Frederick (August-September 1736), Voltaire proposed a new role model to the crown prince: the biblical King Solomon. If Voltaire and Frederick did not regard the Bible as a blueprint for modern politics, they knew well how to make use of it when opportunity called. Voltaire could not

${ }^{35}$ Felicia Gottmann, 'Du Châtelet, Voltaire, and the transformation of Mandeville's Fable', History of European Ideas, 38 (2012), pp. 218-32. Du Châtelet's version of Mandeville's Fable is available as an appendix in Ira O. Wade, Studies on Voltaire: with some unpublished papers of Mme du Châtelet (Princeton, NJ, 1947).

${ }^{36}$ See W. H. Barber's introduction to the Traité in $O C V$, XIV, pp. 384-7, 409-11.

${ }^{37}$ OCV, XVI, pp. 295-303. See Haydn Mason's introduction to Le Mondain (ibid., pp. 273-88); Nicholas Cronk, 'The Epicurean spirit: champagne and the defence of poetry in Voltaire's Le Mondain', Studies on Voltaire and the Eighteenth Century, 371 (1999), 53-80; Wade, Studies on Voltaire, pp. 49-56.

${ }^{38}$ OCV, XVI, p. 296.

39 'The illustrious [seventeenth-century Swedish] Queen Christina abandoned her kingdom to look for the arts; govern, Sir, and let the arts come looking for you' (Voltaire to Frederick, 26 Aug. 1736, in $O F G$, XXI, p. 8). For an exhortation to continue writing rhymed verse, see Voltaire to Frederick, [12?] Oct. 1737 (D1375), in $O C V$, LXXXVIII, p. 380. 
ignore the case of a rare king of Israel renowned not only for his wisdom and philosophical authorship but also for generating unprecedented prosperity and wealth. Both modern Europe and Solomon's kingdom linked distant continents through naval commerce, powered by the benevolent pursuit of luxury and 'abundance'. ${ }^{40}$ This term, now associated with Solomon and recommended as a political goal to Frederick, was one of the concepts derided by Fénelon and revaluated in Le Mondain of the same year as the poem to the crown prince. In Voltaire's Défense du Mondain against his (and luxury's) critics, Solomon featured as an exemplary king who employed luxury in the service of national well-being and his own happiness. ${ }^{41}$ Solomon also ruled over a sizeable kingdom, which allowed Voltaire to make the point that luxury was wholesome in states possessing a large territory but detrimental to small republics. ${ }^{42}$

Voltaire thus made in 1736-7 a concerted effort to link the defence of luxury and modern commerce to the figure of an earthly philosopher-king pursuing his selflove while promoting the well-being of his state. Frederick had to become le Salomon $d u$ Nord, as Voltaire would crown him after his accession to the throne. ${ }^{43}$ Most significantly, through Solomon's example Voltaire suggested to Frederick that governing in the interest of the state, like the pursuit of learning, should not come at the expense of personal pleasure.

These are the lessons a sage king should follow

Knowledge, after all, without joy of life is hollow.

Everything aims at happiness, as God did intend,

Knowledge is a means; it must lead to an end.

A know-all king who does not know the art supreme

Of making his people happy and being himself content

Is like a rich miser, tied firmly to his gold,

Piling up a treasure that is hidden and useless...

The more a king is learned, the more he loves his own glory. ${ }^{44}$

Voltaire's point was reiterated a few months later, in a letter to Frederick attached to a copy of his Défense du Mondain. In the Défense itself and in Voltaire's letter, cultural and material magnificence - 'commonly called luxury' - underpinned political greatness instead of threatening public spiritedness. ${ }^{45}$ Even before receiving these texts, Frederick indicated his broad agreement ('my ethics, Sir, matches yours very well'): the pursuit of happiness and self-love was beneficial when free of excess and abuse. ${ }^{46}$

The significance of this early exchange, from summer 1736 to winter 1737 , cannot be overstated. To a large extent, it was a more formative and enduring

\footnotetext{
40 'Le Mondain', lines 22-9, OCV, XVI, p. 296); 'Au prince royal de Prusse', lines 715, ibid., p. 380.

41 'Défense du Mondain' (early 1737), lines 113-19, OCV, XVI, pp. 308-9.

42 'Sachez surtout que le luxe enrichit / Un grand État, s'il en perd un petit' ('Défense du Mondain', $O C V$, XVI, p. 306).

${ }^{43}$ Voltaire to Frederick, 16 Nov. 1743 (D2887), OCV, XCIII, p. 25.

44 'Au prince royal de Prusse' (Sept.-Oct. 1736), lines 76-89, OCV, XVI, pp. 381-2.

${ }^{45}$ Voltaire to Frederick, Jan. 1737 (D1251), OCV, LXXXVIII, p. 190.

${ }^{46}$ Frederick to Voltaire, 16 Jan. 1737 (D1261), OCV, LXXXVIII, p. 205. See also

Voltaire's programmatic letter about ethics (D1376), 15 Oct. 1737: ibid., pp. 381-5.
} 
experience than Voltaire's subsequent sojourn in Potsdam as Frederick's guest, from 1750 to 1753: physical proximity brought about mutual coolness and hostility.

Assuming in the late 1730s the role of unofficial instructor of the crown prince at the latter's enthusiastic invitation, Voltaire actualized the sort of educational relationship imagined by Fénelon between the young prince Telemachus and his tutor, Mentor, while preaching to his own pupil a very different philosophical sermon. Accompanied by an exchange of newly composed writings and a playful discussion of contemporary authors, the correspondence with Voltaire introduced Frederick to the main pro-luxury arguments concerning state and self. Instead of useless hoarding (a potential reference to Frederick's father), a ruler should make money circulate through investment and extensive commerce; trade stood at the basis of flourishing economies; and it was founded on the healthy pursuit of one's own glory. King Solomon allegedly showed the way by aligning his own 'joy of life' (material, intellectual, and sexual) with national well-being, rendering his subjects happy through the benign pursuit of self-love. Frederick would later de-emphasize only a single element of Voltaire's vision of modern monarchy: the almost exclusively peaceful means by which the ruler should pursue his goals, due to the moderating effects of culture and international trade (doux commerce).

Ample evidence of this broader outlook can be found in Frederick's writings from the Anti-Machiavel of 1740 and all the way to the 1770s. Emphasizing the financial and military advantages of large commercial monarchies over ancient or Renaissance city-states, Frederick made this point by reference to the terms that had attracted Fénelon's most violent censure.

Luxurious living, which is born of abundance, and which causes wealth to circulate through the bloodstream of a state, makes a great kingdom flourish; it is luxury which supports industry, and it is luxury that increases the needs of the rich, so as to bind them, through these same needs, to the poor. ('AntiMachiavel', $F G P W$, p. 47; my emphases.)

The rapid pace at which the crown prince appropriated Voltaire's pro-luxury stance, endorsing the pursuit of natural human instincts, did not merely reflect youthful infatuation with a famous interlocutor. Frederick was fully aware of the compatibility between the pro-luxury stance and modern monarchies rather than small republics. As Montesquieu would argue in 1748, large monarchies were best suited to promote and reward the quest for honour and esteem: 'Republics end in luxury; monarchies, in poverty. ${ }^{47}$

After Jean-Jacques Rousseau had skilfully revived elements of the Fénelonian ideology in the 1750s, Frederick renewed his public allegiance to the pro-luxury camp in essays on the themes of Rousseau's early Discourses. In his Discourse on the usefulness of the sciences and the arts within a state (1772), the king responded to Rousseau's thesis that the arts and the sciences were luxuries that had originated in the vanity of their practitioners. For Rousseau, enjoyment of the arts could only come at the expense of political prowess, because they necessarily diverted citizens'

${ }^{47}$ Book VII, ch. 4, in Montesquieu, Spirit of the laws, p. 100; Euvres completes, II, pp. 336-7. Cf. Horst Dreitzel, Monarchiebegriffe in der Fürstengesellschaft (2 vols., Cologne, 1991), II, pp. 732-5. 
attention from the single-minded pursuit of the common good. ${ }^{48}$ For Frederick, however, scientific inventions and cultural achievements were unquestionable markers of national glory. As such, they have always been generated by the benevolent pursuit of self-love and social esteem. ${ }^{49}$

Already in the Anti-Machiavel servitude to the state was not predicated on idealistic self-abnegation. Contrary to the portrayals of ancient republican virtue by Fénelon, Rousseau, and even Montesquieu, Frederick never grounded the ruler's proper action in the elimination of his ambition or the suppression of self-love. He made a clear distinction between l'intérêt - material gains pursued with no regard to the common good - and amour-propre, a healthy love of self that was a fundamental element of morality and benevolent kingship. The fullest elaboration of the link between self-esteem and the common good, the lesson learned from Voltaire in the late 1730s, can be found in Frederick's Essay on self-love, considered as a principle of morality (1770). Although it was also a reply to works written in the late 1760s, Rousseau's Discourse on inequality was a major target of the King's Essay on selflove.

Rousseau had contrasted self-love (amour-propre), which he saw as an excessive drive for recognition and domination, with a benign care of the self or basic self-preservation (amour de soi-même). Self-love was the corruption of the natural instinct for self-preservation, Rousseau argued, because it depended on the affirmation of one's worth by others. ${ }^{50}$ For Frederick, this could not be farther from the truth, because 'the examples that we have of the greatest absence of self-interest (désintéressement) stem from the principles of self-love.' (FGPW, p. 146) The key to the proper regulation of self-love was understanding that others' interests could be conceived as one's own, and aligning one's self-love with the common good. This was a form of Stoic oikeiosis, the rational extension of self-love to encompass gradually one's family and fellow citizens.

Here, in 1770, Frederick went beyond Voltaire, advocating a Hellenistic view of happiness as a perfect peace of mind. The pursuit of such mental tranquillity would teach us not to attach ourselves vehemently to tempestuous passions, which - if we could not satisfy them - might only trouble us. According to the mature Frederick, 'there is no other felicity in this world...than peace of mind' (FGPW, p. 143).

The king was well aware that his 'peace of mind' (la tranquillité de l'âme) was highly reminiscent of the equivalent term in ancient Epicurean philosophy, ataraxia, and its Stoic version, apatheia. This royal resuscitation of pagan ethics was complemented by a ringing condemnation of those who could not reconcile self-love and fellow-feeling. First and foremost among Frederick's targets were the monotheistic faiths, charged with advocating the wrong sort of ethics. The anchoring of morals in a wrathful God or in divine rewards and punishments was a serious obstacle to the proper motivation of virtuous action.

How many degenerate Christians there were who corrupted the pure morality

\footnotetext{
${ }^{48}$ Rousseau, 'Discourse on the sciences and arts', in The discourses and other early political writings, ed. Victor Gourevitch (Cambridge, 1997), pp. 1-28.

${ }^{49}$ OFG, IX, pp. 195-207.

${ }^{50}$ Rousseau, Discourses, 218.
} 
of antiquity! Greed, ambition, and fanaticism filled the hearts of those who professed the renunciation of the world, and destroyed all that simple virtue had established. History teems with such examples. In summary, with the exception of a few reclusives who were both pious and useless to society, the Christians of today are no better than were the Romans of the time of Marius and Sulla; but, of course, I am restricting this parallel purely to the comparison of customs.('An essay on self-love, considered as a principle of morality', $F G P W$, p. 140)

Come now, cowardly Christians, let fears of eternal fire

Prevent you from indulging your criminal desires,

Your austere virtue is nothing more than show.

But we, who renounce all future rewards,

Who do not believe in your eternal torments,

Who have never let self-interest (l'intérêt) sully our sentiments;

It is the good of mankind, it is virtue that moves us...

('Epistle XVIII: To Keith, on the vain terrors of death and the fears of another life', $F G P W$, p. 115)

Frederick's rehabilitation of self-love as an ethical principle was, therefore, meant to offer an alternative to virtue as self-denial, which the king attributed to the motley crew of Christians, ancient republicans, Fénelon, and Jean-Jacques Rousseau. ${ }^{51}$ According to Frederick, self-love could generate on its own all the sociable and patriotic drives usually deemed virtuous. It is disinterestedness in the guise of selfabnegation and withdrawal from this world that Frederick saw as detrimental to both individual health and the social fabric.

The largely Stoic channelling of healthy self-love into the pursuit of the common good linked Frederick's notions of patriotism and servitude to the state to his endorsement of luxury and pleasure. The efficacy of monarchical government depended on the king's alignment of his natural love of esteem with the well-being of the state. Once this balance had been achieved, he could openly base his rule on an initial social contract. Peculiar as this synthesis may have been, it did not involve a purely idealistic or 'humanitarian' view of politics, as Meinecke and others have suggested. ${ }^{52}$ The king's function as the first servant of the state was by no means governed by a self-denying principle of pure morality. It was part and parcel of an eighteenth-century conception of modern kingship in commercial society, which Frederick developed early on with Voltaire and retained throughout his career despite substantial changes of authorial tone and register. While the Anti-Machiavel differs from most of the king's mature work in its youthful enthusiasm and lack of

\footnotetext{
${ }^{51}$ Frederick was not aware of Rousseau's later, more positive reconceptualization of self-love (which resembled his own) in Émile, or on education (1762). See Avi Lifschitz, 'Adrastus versus Diogenes: Frederick the Great and Jean-Jacques Rousseau on self-love', in Avi Lifschitz, ed., Engaging with Rousseau (Cambridge, 2016), pp. 17-32.

${ }^{52}$ Meinecke, Idee der Staatsräson, pp. 354-6. Eduard Zeller compared Frederick's sense of obligation to the state to Kant's disinterested moral duty, while recognizing an irresolvable tension with the king's endorsement of the pursuit of self-love (Zeller, Friedrich als Philosoph, pp. 69-70).
} 
executive experience, Frederick would keep emphasizing distinct elements of his early philosophical ideas on different occasions and for a variety of purposes.

Yet did this modern synthesis amount to more than an apology for despotism in the name of public happiness? It did differ from earlier philosophical invocations of a social contract in the service of absolutist government due to another specific aspect of Frederick's notion of kingship. This was a point on which he repeatedly insisted, even if it was not formally codified in contemporary Prussia: the accountability of the monarch to his people. As Frederick put it, 'He [the prince] is no more than the first servant of the state, obliged to act with probity, with wisdom, and with total disinterest, as if at any moment he were to be held to account for his administration by his subjects.' ('Essay on the forms of government and the duties of sovereigns', $F G P W$, p. 205) The king's emphasis on accountability was closely linked to his stance on censorship, the freedom of thought, and public debate. It is by allowing a generous measure of free discussion - rather than establishing institutional checks and balances - that the government could become well informed, the better to align its conduct with the citizens' wishes and well-being. According to Frederick, the ruler had no leverage over his subjects' belief systems, which were outside the scope of the original social contract. Therefore, he could tolerate unflattering views of his government as long as they were not accompanied by disobedience or disorder.

It is indeed in the public sphere that the king could be held to account, a lesson Frederick learned from the critical responses to the Anti-Machiavel (1740) and the illicit publication of his scurrilous philosophical poems (1760). Shrewdly transforming his initial resentment of the unregulated (and unregulatable) print market into a major tenet of his philosophy, the king eventually presented the uncontrollable character of the public sphere as an informal check on his political conduct. Well aware of his unique role as a writing and publishing monarch, Frederick mobilized open criticism to his advantage by construing it as a logical extension of his subjects' freedoms of worship and belief. For Frederick, only public opinion - a significant phenomenon in the second half of the eighteenth century, following a major expansion of readership and the print market - could constrain the utterances and actions of rulers. ${ }^{53}$

The link between the limits of absolute power and the norms restricting the public use of language was made explicit in Frederick's Essay on German literature (1780). In this misinformed critique of contemporary German culture, the king floated the possibility of a reform of pronunciation that would render the German language more melodic, in a manner similar to Romance languages. Yet Frederick immediately added that such a reform, even if solemnly decreed by the Holy Roman Emperor and

${ }^{53}$ On public opinion and debate in print, especially in Germany, see Jürgen Habermas, The structural transformation of the public sphere, trans. Thomas Burger and Frederick Lawrence (Cambridge, MA, 1989), pp. 71-117; Anthony La Vopa, 'Conceiving a public: ideas and society in eighteenth-century Europe', Journal of Modern History, 64 (1992), pp. 79-116; T. C. W. Blanning, The culture of power and the power of culture: Old Regime Europe 1660-1789 (Oxford, 2002), pp. 194-232; Ursula Goldenbaum et al., Appell an das Publikum: Die öffentliche Debatte in der deutschen Aufklärung 1687-1796 (Berlin, 2004). 
all his Electors, would have no practical effect. The people, 'who are the arbiters of language in every country, would continue to pronounce words in the usual way'. The obvious reply to the imperial edict would be that the emperor himself was subject to the rules of grammar, controlled as they were by impersonal public use: 'Caesar is not above the grammarians. ${ }^{54}$

This reference to popular use and the defiance of political imposition did not remain an isolated anecdote in a text ostensibly addressing literary issues. In 1784, Immanuel Kant appropriated Frederick's parallel between the constraints imposed upon authors by the public use of language and the political limitations that public opinion placed upon the king. In his essay What is enlightenment?, Kant's argument for the freedom of thought and expression drew on Frederick's point that rulers must allow their subjects to define freely what was necessary for their own salvation. For this purpose, the philosopher of Königsberg quoted back at Frederick his own phrase from the Essay on German literature.

It indeed detracts from his majesty if he interferes in these affairs by subjecting the writings in which his subjects attempt to clarify their religious ideas to governmental supervision. This applies if he does so upon his own exalted opinions - in which case he exposes himself to the reproach: Caesar non est supra Grammaticos - but much more so if he demeans his high authority so far as to support the spiritual despotism of a few tyrants within his state against the rest of his subjects. ${ }^{55}$

It is tempting to read Kant's What is Enlightenment? as a panegyric to Frederick, almost a funerary oration written two years before the king's death. Yet the praise Kant showered on Frederick was heavily qualified. It depended upon a certain course of action, announced and enacted by Frederick himself. If the king - or his successors, a more likely target for Kant in 1784 - deviated from this path, the 'greatness' with which Kant endowed the king of Prussia would fade away. Kant did in this essay precisely what the king had advocated in his political writings: he publicly held Frederick to account in front of his subjects by referring to his published work, regardless of whether Frederick was sincere at the time of writing.

A few months before the publication of Kant's essay, the Prussian jurist Ernst Ferdinand Klein acted in a similar way. He published in the same periodical, Berlinische Monatsschrift, an essay entitled 'On the freedom of thought and of the press: for princes, ministers and writers' (Über Denk- und Drukfreiheit. An Fürsten, Minister, und Schriftsteller). The core of this essay was an imagined speech by Frederick, cobbled together by Klein from different utterances of the Prussian king in several of his written works (especially his philosophical poems). While some of the points were taken out of context in this crafted speech, the message to Frederick was clear: do not stray away from a course of action which you have endorsed yourself.

Frederick of Prussia has had an influence on his contemporaries for almost half a century by means of his writings and, even more, by his example...But

\footnotetext{
54 'De la Littérature Allemande; des defauts qu'on peut lui reprocher; quelles en sont les causes, et par quels moyens on peut les corriger', in OFG, VII, p. 120.

${ }^{55}$ Immanuel Kant, Political writings, ed. Hans Reiss, trans. H. B. Nisbet (Cambridge, 1991), p. 58.
} 
nothing can be more useful for my purposes, I believe, than to collect what Frederick has thought and said on this matter and lay it before my readers. I cannot boast of having received special revelations from him: I can only extract appropriate materials from his writings, which lie before the eyes of everyone. ${ }^{56}$

It is the public availability of Frederick's published works that enabled Klein to hold his monarch to account. By the mere act of writing and publishing, Frederick accepted the uncontrollable verdict of the reading and debating public - despite his occasional exasperation with, or personal contempt towards, members of this public. ${ }^{57}$

In the final decade of Frederick's reign, residents of Brandenburg-Prussia took pride in the relative freedom of local discussions of politics, which was not lost on foreigners as well. The British physician John Moore, visiting Berlin in the 1770s, was surprised to find 'ticklish' political issues discussed openly 'with as little ceremony as at a London coffee-house'. This applied even to pamphlets attacking the king's role in the first partition of Poland.$^{58}$ Count Mirabeau, who was on a diplomatic mission in Berlin in 1786-87, credited the recently deceased king with extensive toleration of religious minorities and public discussion. He was particularly impressed by the cultural and material prosperity of the Jewish community in Berlin, despite the existing legal discrimination. Frederick, like Voltaire, was not particularly well disposed towards the Jews; Mirabeau essentially praised the benevolent effects of his passivity in this respect. By letting the Jews pursue their cultural and economic self-improvement, the king rendered them 'useful' citizens of Prussia. ${ }^{59}$ As to public debate, if Frederick did not allow complete freedom of expression, especially on military affairs, he at least extended it well beyond its usual confines elsewhere. At the end of the late king's reign, according to the French observer, his policies in this regard had spread beyond Prussia's borders, to the extent that 'today one can discuss across Germany, at least in a theoretical manner, any issue of theology, philosophy, economy, and politics'. ${ }^{60}$

These testimonies and others over-ride what is arguably the most renowned critique of Frederick in this context. ${ }^{61}$ The status of the critic, Gotthold Ephraim

${ }^{56}$ Ernst Ferdinand Klein, 'The freedom of thought and of the press', trans. John Christian Laursen, in What is enlightenment?, ed. James Schmidt (Berkeley, CA, 1996), p. 88. Originally published in Berlinische Monatsschrift, 3 (1784), pp. 312-30. ${ }^{57}$ Blanning, Frederick the Great: King of Prussia (London, 2015), pp. 335-9.

58 John Moore, A view of society and manners in France, Switzerland, and Germany, (2 vols., London, 1779), II, p. 187.

59 'Here is what a single man has brought about, without the help of legislation. One should well reflect how generous goodwill (liberrale bienveillance) on behalf of the government made this great work happen' (Honoré Gabriel Riquetti, comte de Mirabeau, De la monarchie prussienne sous Frédéric le Grand, v (London, 1788), p. 58). Mirabeau's focus on a few Berlin-based families did not capture the serious discrimination suffered by most Jews in Prussia; see Tobias Schenk, Wegbereiter der Emanzipation? Studien zur Judenpolitik des 'Aufgeklärten Absolutismus' in Preußen (1763-1812) (Berlin, 2010).

${ }^{60}$ Mirabeau, De la monarchie prussienne, v, p. 348.

${ }^{61}$ For an overview of public discussion in Prussia in the early 1780s, see Horst Möller, Vernunft und Kritik. Deutsche Aufklärung im 17. und 18. Jahrhundert (Frankfurt am Main, 1986), pp. 281-307. 
Lessing - one of the founding fathers of modern German literature - has lent substantial weight to the assertion that the king's much-touted freedom of expression was merely a cynical ploy. Having left Prussia in 1760 (though still periodically visiting Berlin), Lessing ridiculed from Hamburg the famous 'Berlin freedom' which amounted 'solely and only to the freedom of publishing as much nonsense against religion as one wishes; an honourable man must be ashamed to make use of such a liberty'. Proper self-expression in political matters would be duly chastised, demonstrating that Prussia was 'the most slavish state in Europe' ${ }^{62}$ Although Lessing's correspondent, the Berlin publisher-author Friedrich Nicolai, was in a much better position to exercise judgement, his reply to Lessing's allegations has rarely been noted. Despite the existing constraints, in Prussia one could write much more freely against despotism and for the rights of the people than in Austria, Nicolai argued, referring to reports about the confiscation of Moses Mendelssohn's Phädon in Vienna. More generally, Nicolai made a distinction between political and scholarly freedom (politische/gelehrte Freiheit). In an absolute monarchy, 'where I take no part in government', there could be no full political freedom: this applied to Prussia and Austria alike. Under Frederick, however, Nicolai and his fellow authors felt they enjoyed extensive scholarly freedom to write, publish, and debate. By comparison, Nicolai replied to Lessing, their Austrian peers lived in scholarly slavery. ${ }^{63}$

Both Nicolai in 1769 and Kant in 1784 referred to an almost complete scholarly freedom, the intellectual liberty to engage in free discussion of political and religious matters in the public sphere. Indeed, the qualification 'as a scholar' appears time and again in Kant's What is Enlightenment? where freedom is concerned. Kant tightly linked 'the public use of reason', which must remain free at all times, to one's capacity 'as a scholar' in the realm of written and printed debate, dichotomously separating it from one's professional activities as a clergyman, an officer, or a tax collector. Distilling a theoretical statement from the conditions in BrandenburgPrussia of his time, Kant distinguished between the public and private use of reason in a manner that mirrored Nicolai's differentiation, fifteen years earlier, between scholarly and political freedom.

The public use of man's reason must always be free, and it alone can bring about enlightenment among men; the private use of reason may quite often be narrowly restricted, however, without due hindrance to the progress of enlightenment. But by the public use of one's own reason I mean the use which anyone may make of it as a man of learning (als Gelehrter) addressing the entire reading public. What I term the private use of reason is that which a person may make of it in a particular civil post or office with which he is entrusted. ${ }^{64}$

${ }^{62}$ Lessing to Nicolai, 25 Aug. 1769, in Gotthold Ephraim Lessing, Sämtliche Schriften, ed. Karl Lachmann and Franz Muncker (23 vols, Leipzig, 1886-1924), XVII, p. 298.

${ }^{63}$ Nicolai to Lessing, 29 Aug. 1769, in ibid., XIX, p. 315. Under Frederick II's successor, Frederick William II, the remit of censorship was significantly extended in an edict of 19 Dec. 1788. In 1794, Nicolai's journal, Allgemeine Deutsche Bibliothek, was proscribed in several Prussian provinces, although it had been sold in 1792 to a non-Prussian publisher (Möller, Vernunft und Kritik, p. 283).

${ }^{64}$ Kant, Political writings, p. 55 (original emphases). 
Contrary to modern connotations, for Kant the duly restricted private use of reason concerned one's political function within the state, a notion parallel to Nicolai's political freedom. The public use of reason was, on the other hand, the equivalent of Nicolai's scholarly freedom to address an audience of readers in print.

Complimentary as Nicolai and Kant were of their king, they both put their finger on the sorely missing elements in Frederick's Prussia: citizens' participation in government through any sort of representative mechanism, and firm institutional guarantees of individual freedom. Indeed, Nicolai's and Kant's distinction between the political and the scholarly reflected, to a large extent, Frederick's own vision of accountability in the public sphere. This did not primarily concern specific affairs of state but rather philosophy in its broader eighteenth-century sense, including political thought, belles-lettres, the sciences, and the fine arts. Despite Frederick's novel reconceptualization of kingship, he championed a paternalistic view of the state where citizens could make their voice heard in printed form, 'as scholars', hoping that the government would take heed.

It is thus no wonder that in 1784 members of the Prussian intelligentsia chose to interpret Frederick's unusual public consultation on a new legal code as a first step towards constitutionalism - which, with any luck, would include guarantees of personal freedom. In What is Enlightenment? of the same year, Kant allowed himself a brief foray into legislative matters, noting hopefully that

the attitude of mind of a head of state who favours freedom in the arts and the sciences extends even further, for he realizes there is no danger even to his legislation if he allows his subjects to make public use of their own reason and to put before the public their thoughts on better ways of drawing up laws, even if this entails forthright criticism of the current legislation. ${ }^{65}$

This optimism was, alas, short-lived. Even the draft legal code of the mid-1780s balanced traditional privileges with declaratory statements about the popular foundation of the state and the duties of its rulers. Further watered down under Frederick's successor, it would subsequently be published as the Allgemeines Landrecht of $1794 .{ }^{66}$ Ultimately, Frederick's idiosyncratic tightrope walk proved too unstable to last: in the absence of a written constitution or representative bodies, his reforms depended on his own person. Mirabeau's tribute to Frederick concerning the toleration of the Jews could thus be read, after the king's death, as criticism: 'Here is what a single man has brought about, without the help of legislation' - or beyond the scope of existing legislation. ${ }^{67}$

\footnotetext{
${ }^{65}$ Ibid., p. 59 (original emphases).

${ }^{66}$ On the transformation of the draft legal code (Gesetzbuch) of the mid-1780s into the 1794 Allegemeines Landrecht, see Günter Birtsch, 'Reformabsolutismus und Gesetzesstaat: Rechtsauffassung und Justizpolitik Friedrichs des Großen', in Günter Birtsch and Dietmar Willoweit, eds., Reformabsolutismus und ständische Gesellschaft (Berlin, 1998), pp. 47-62; Thomas Finkenauer, 'Vom Allgemeinen Gesetzbuch zum Allgemeinen Landrecht - preußische Gesetzgebung in der Krise', Zeitschrift der Savigny-Stiftung für Rechtsgeschichte (Germanistische Abteilung), 113 (1996), 40216.

${ }^{67}$ See note 59 above.
} 
It would be, however, a mistake to conclude retrospectively that the institutional shortcomings of eighteenth-century Prussia render Frederick's writings mere theoretical distractions from a highly despotic reality. Even if we chose to discount Prussian contemporaries' pride in their relative freedom of thought and expression, in the most extensive religious toleration in Europe, or in a vigorous public sphere, we should still appreciate the original elements in the king's writings. His works included an unprecedented royal endorsement of social contract theory, an attack on the divine right of rulers, and a new conceptualization of the king's role in a commercial society based on the pursuit of self-love and luxury (rather than a Calvinist or quasirepublican espousal of self-denying kingship). On the ethical and the religious fronts, Frederick's promotion of the freedom of worship and opinion was accompanied by his peculiar endorsement of largely pagan ethics and a sharp critique of the foundations of Christian morality. ${ }^{68}$ All these aspects of the king's authorial labour constituted an integral part of his political agency, publicly placing constraints on his conduct. As cynical and self-seeking as Frederick may have been, his philosophical writings mattered also because contemporaries used them as a means of holding him to account in the public sphere, 'as scholars' - and Frederick listened sometimes, if not at all times, to such voices.

Alexis de Tocqueville was no naïve admirer of Frederick the Great. In a long footnote on the Prussian Allgemeines Landrecht, Tocqueville noted that the legal code employed the modern language of rights and reascribed royal power simply to the state. These elements, however, did not mitigate the conservative, at times even reactionary, character of the code (revised under Frederick's successor). ${ }^{69}$ It may have been that in this respect too Frederick, for Tocqueville, was a 'precursor and, in a manner of speaking, an agent' of the French Revolution. The philosopher-king of Prussia harnessed the language of accountability and rights to a centralizing political thrust, while reshaping the accepted political vocabulary and channelling it in new directions.

\footnotetext{
${ }^{68}$ This critique was more attenuated in his reviews of d'Holbach's works in 1770.

${ }^{69}$ Tocqueville, The ancien régime, ed. Elster, pp. 201-5; Tocqueville, L'ancien régime, ed. Mayer, pp. 345-50.
} 